\title{
Semi-automated micromethod for estimating the unsaturated iron-binding capacity of serum using radioactive iron
}

\author{
B. BROZOVICH AND J. COPESTAKE \\ From the Department of Haematology, St Bartholomew's Hospital, London
}

SYNOPSIS A semi-automated micromethod for the determination of the unsaturated iron-binding capacity (UIBC) of serum using radioactive iron and magnesium carbonate as an adsorbing substance is presented. The method has the advantage of simplicity and speed. The determination of UIBC is carried out on $0.1 \mathrm{ml}$ of serum in duplicate, using autodiluters, at the rate of up to 200 sera per day. The reproducibility of the presented method is comparable to the reproducibility of other methods for the determination of iron-binding capacity. As the method is a simple one it can easily be introduced into laboratories with facilities for radioactive counting.

In serum, iron is bound to its carrier protein, a beta-1-globulin, transferrin. The transferrin concentration in healthy persons is in the range of 200 to $320 \mathrm{mg} / 100 \mathrm{ml}$ of serum, which corresponds to a total iron-binding capacity (TIBC) of 250 to $400 \mu \mathrm{g}$ $\mathrm{Fe} / 100 \mathrm{ml}$ (Bothwell and Finch, 1962). Approximately one-third of the transferrin is saturated with iron; the remainder represents the unsaturated iron-binding capacity (UIBC). The significance of a change in the concentration and saturation of transferrin in various diseases has been reviewed in detail by Bothwell and Finch (1962). The determination of TIBC or UIBC, together with the serum iron estimation, is now a routine procedure in most hospital laboratories.

Nearly 50 different methods for the determination of iron-binding capacity in serum have been described and most of these employ colorimetric (Laurell, 1947; Ramsey, 1957; Caraway, 1963) or radioactive techniques (Bothwell, Jacobs, and Kamener, 1959; Tauxe, 1961; Herbert, Gottlieb, Lau, Fisher, Gervirtz, and Wasserman, 1966). Other techniques for the estimation of TIBC or UIBC have also been described, for example, the immunodiffusion method (Jager and Gubler, 1952; Soothill, 1962), the gel filtration method (Barber, Dempster, and Anderson, 1963), and the atomic absorption spectroscopy method (Rodgerson and Helfer, 1966; Zettner, Sylvia, and Capacho-Delgado, 1966), but these are infrequently used in routine Received for publication 22 January 1969. work. Of all these methods, however, none can be used satisfactorily when only a small volume of serum is available and/or a large number of samples are to be assayed, as in population surveys, paedriatic work, and experimental work on small laboratory animals. The micromethods for determination of iron-binding capacity (Lee and Chiamori, 1961; Caraway, 1963; Watkins and Butler, 1966) are laborious and permit only a small number of sera to be assayed. The semi-automated methods using an AutoAnalyzer (Young and Hicks, 1965; Zak and Epstein, 1964; Giovanniello, Di Benedetto, Palmer, and Peters, 1968) require at least $1.0 \mathrm{ml}$ of serum, with the exception of the micromethods of Garry and Owen (1967) and Clarke and Nicklas (1967). On the other hand, even with the fully automated AutoAnalyzer method for TIBC determination (Giovanniello et al, 1968), the rate of analysis is limited to 20 samples per hour. It therefore seemed worthwhile to develop a method which would measure the UIBC in small volumes of a large number of sera. For this purpose the radioactive iron method for the determination of UIBC, developed in this laboratory (Brozovich, 1968), was modified and partially automated using autodiluters and autodispensers.

The purpose of this paper is to present a simple, semi-automated micromethod for the determination of UIBC using radioactive iron with magnesium carbonate as the adsorbing substance and to compare it with the method previously described 
(Brozovich, 1968). In addition, the comparison is made between the UIBC values of a small number of sera determined by the method described below and those obtained using three other methods.

\section{MATERIAL AND METHODS}

The determination of UIBC was carried out on sera from healthy persons and patients suffering from various diseases.

COLLECTION AND STORAGE OF SAMPLES Samples of venous blood, taken with plastic syringes (Johnson's Ethical Plastics Ltd), were placed in plastic tubes (Luckham Ltd) made iron free by standard procedures. After separation of serum, samples were assayed immediately or deep frozen until the measurements were carried out. Comparative measurements on one sample were made on the same day. Iron-free glassware was used throughout.

SERUM IRON AND TIBC DETERMINATION These tests were carried out on a number of sera using the methods of Caraway (1963) and Garry and Owen (1967). The UIBC obtained by these methods was calculated by subtracting the serum iron from the total iron-binding capacity.

UNSATURATED IRON-BINDING CAPACITY This was estimated on duplicate samples using the method described in this paper and the method of Brozovich (1968).

SEMI-AUTOMATED MICROMETHOD FOR DETERMINATION OF UIBC Analar reagents and glass-distilled water were used throughout.

Radioactive ferric chloride For the stock solution $9.6 \mathrm{~g}$ of $\mathrm{FeCl}_{3} \cdot 6 \mathrm{H}_{2} \mathrm{O}$ was dissolved in $100 \mathrm{ml}$ of $0.1 \mathrm{~N}$ $\mathrm{HCl} ; 0.5 \mathrm{ml}$ of this solution was diluted to $100 \mathrm{ml}$ with $0.1 \mathrm{~N} \mathrm{HCl}$. For the working solution $2.5 \mathrm{ml}$ of the stock solution was pipetted into a $100-\mathrm{ml}$ flask, approximately $10 \mu \mathrm{c}$ of radioactive iron (radioactive ferric chloride in $0 \cdot 1 \mathrm{~N} \mathrm{HCl}$, Radiochemical Centre, Amersham) was added and the solution was diluted to $100 \mathrm{ml}$ with water. The iron content was $2.5 \mu \mathrm{g} / \mathrm{ml}$ in $0.025 \mathrm{~N} \mathrm{HCl}$. However, the exact amount of iron was accurately measured by one of the methods for iron determination.

Barbital buffer Sodium chloride, $6.4 \mathrm{~g}$, and $2.3 \mathrm{~g}$ of sodium barbiturate were dissolved in a 1 litre flask with approximately $700 \mathrm{ml}$ of water. Then $6.0 \mathrm{~g}$ of diethylbarbituric acid was added, dissolved, and the volume made up to $1,000 \mathrm{ml}$. The $p \mathrm{H}$ of this solution was 7·4.

Magnesium carbonate Anhydrous, light powder, was used.

Assay protocol Sera were pipetted by an autodiluter (Hook \& Tucker, Mk. I) with barbital buffer as the diluent into plastic disposable tubes $\left(2 \frac{1}{2} \times \frac{3}{8}\right.$ in. polystyrene, M. \& H. Precision Engineering Co. Ltd). These tubes were shown to be sufficiently iron free without washing. The sample volume was set at $0.1 \mathrm{ml}$ and the sample to diluent ratio was 1:5. Radioactive iron, $0.4 \mathrm{ml}$, was added by hand or by an autodispenser. Samples were mixed on a Vortex mixer, and left to stand for five minutes. Magnesium carbonate, approximately $50 \mathrm{mg}$, was added by hand using a Pasteur pipette previously cali : brated. Tubes were stoppered with iron-free rubber stop pers, and mixed for 30 minutes on a turntable. Aftermixing, the tubes were centrifuged for 10 minutes at $2,000=$ rpm. Aliquots of supernatant were pipetted by an auto $\frac{\bar{C}}{\mathrm{C}}$ diluter (Hook \& Tucker, Mk.II), with saline as the diluent, into plastic tubes for radioactive counting. The samplee volume was set at $0.5 \mathrm{ml}$ and the sample to diluent ratios was $1: 3$. The tubes were stoppered, placed in plastic counting tubes (Packard), and the radioactivity was. counted. A number of standards were set up using $\overrightarrow{\vec{H}}$ radioactive iron solution instead of serum, and buffer $\omega$ instead of radioactive iron solution. No magnesiumt $\bar{\sigma}$ carbonate was added. Aliquots of the standard solution? were taken for radioactive counting. The UIBC inN $\mu \mathrm{g} \mathrm{Fe} / 100 \mathrm{ml}$ of serum was calculated from in Radioactivity of sample $\times$ iron content of working Radioactivity of standard $\times$ iron content of working $\mathcal{O}$ solution $(\mu \mathrm{g} \mathrm{Fe} / 100 \mathrm{ml})$.

Recovery of transferrin The recovery of transferrin was $\vec{\oplus}$ estimated using human transferrin (Behringwerke A.G.) $\mathbb{D}$ shown to be $100 \%$ pure on acetate cellulose electrophoresis. The transferrin was added to a serum of known 3 UIBC and the increase in UIBC measured. The recovery was represented by the difference between the UIBC of the serum before and after the addition of the transferrin, $\vec{\varphi}$

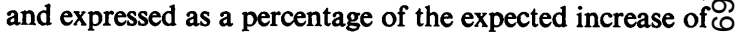
UIBC, calculated on the basis that $1 \mathrm{mg}$ of transferrin is capable of binding $1.25 \mu \mathrm{g}$ of iron.

Apparatus A Unicam SP 600 spectrophotometer and a Technicon AutoAnalyzer were used for colorimetric $\bar{D}$ measurements and a Packard Auto Gamma counter (model 5213) for radioactive counting. Calculation of $\stackrel{\AA}{\AA}$ results and statistical analysis was done on a programmed $\vec{F}$ Olivetti P 203 calculator.

\section{RESULTS}

REPRODUCIBILITY OF THE SEMI-AUTOMATED MICRO-융 METHOD FOR UIBC DETERMINATION The repro- ducibility of the autodiluters was tested for sampling precision and possible carry over. First, 48 samples of $ᄋ$ radioactive iron solution were set up as described in 3 the assay protocol for standards. For this level of 음 radioactivity, which represented a UIBC of $250 \mu \mathrm{g} D$ $\mathrm{Fe} / 100 \mathrm{ml}$, the coefficient of variation was $1.33 \%$. This combines the sampling error of the autodiluters $\mathrm{N}$ and the counting error (which was less than $1 \%$ ). Therefore, the error due to sampling procedure was $\mathrm{N}$ negligible. Secondly, when radioactive iron solution $N$ and distilled water were alternately sampled, the tubes containing water had background activity. There was no difference in the number of counts $\frac{\bar{D}}{\mathrm{D}}$ when samples with radioactive iron were sampled in succession or followed by water samples. Thus, $\square$ no carry over was detectable.

The overall reproducibility of the semi-automated micromethod for UIBC determination was tested by means of (1) the coefficient of variation obtained on 
multiple estimations on one sample; (2) the combined coefficient of variation between a number of duplicate samples with UIBC ranging from 100 to $600 \mu \mathrm{g} \mathrm{Fe} / 100 \mathrm{ml}$; and (3) the recovery of transferrin added to serum samples. Using these parameters the semi-automated micromethod for the determination of UIBC was compared with the method of Brozovich (1968) (Table I). It was shown that both methods are equally reproducible. In addition, the UIBC was measured on a batch of sera using the semi-automated micromethod on three consecutive days, each time with freshly made reagents. The difference between the UIBC values obtained on different days was within the limits of variation for the method (Table II).

\section{TABLE I}

REPRODUCIBILITY OF THE SEMI-AUTOMATED MICROMETHOD USING RADIOACTIVE IRON AND MAGNESIUM CARBONATE AND THE METHOD OF BROZOVICH (1968)

\begin{tabular}{|c|c|c|}
\hline & \multicolumn{2}{|l|}{ Method } \\
\hline & $\begin{array}{l}\text { Semi-automated } \\
\text { Micromethod }\end{array}$ & $\begin{array}{l}\text { Brozovich } \\
\text { (1968) }\end{array}$ \\
\hline Coefficient of variation (\%) & $\begin{array}{l}2 \cdot 6(10)^{1} \\
2 \cdot 3(20) \\
0 \cdot 6(10)\end{array}$ & $\begin{array}{l}3 \cdot 1(10) \\
3 \cdot 2(9) \\
1 \cdot 9(6)\end{array}$ \\
\hline $\begin{array}{l}\text { Combined coefficient of } \\
\text { variation between duplicate } \\
\text { estimations (\%) }\end{array}$ & $2 \cdot 2(50)^{2}$ & $3.5(27)$ \\
\hline Transferrin recovery $(\%)^{3}$ & 98 & 98 \\
\hline
\end{tabular}

${ }^{1}$ Number of estimations on one sample.

${ }^{2}$ Number of duplicate estimations.

'Estimated on four duplicate samples.

\section{TABLE II}

COMPARISON OF UIBC OF A BATCH OF SERA OBTAINED BY A SEMI-AUTOMATIC MICROMETHOD ON THREE CONSECUTIVE DAYS

Measurement of UIBC ( $\mu \mathrm{gFe} / 100 \mathrm{ml})$ on Three Days

\begin{tabular}{llll} 
Sample & & & \\
No. & First & Second & Third \\
\hline 1 & 186 & 194 & 197 \\
2 & 179 & 178 & 179 \\
3 & 283 & 298 & 298 \\
4 & 166 & 172 & 165 \\
5 & 315 & 337 & 327 \\
6 & 355 & 367 & 366 \\
7 & 311 & 319 & 335 \\
8 & 309 & 323 & 325 \\
9 & 442 & 432 & 440 \\
10 & 318 & 323 & 331 \\
11 & 293 & 310 & 317 \\
12 & 316 & 337 & 332 \\
13 & 281 & 295 & 295 \\
14 & 258 & 271 & 279 \\
15 & 291 & 301 & 308 \\
16 & 247 & 250 & 254 \\
17 & 304 & 316 & 324 \\
18 & 195 & 213 & 211 \\
19 & 526 & 553 & 543 \\
20 & 205 & 201 & 228
\end{tabular}

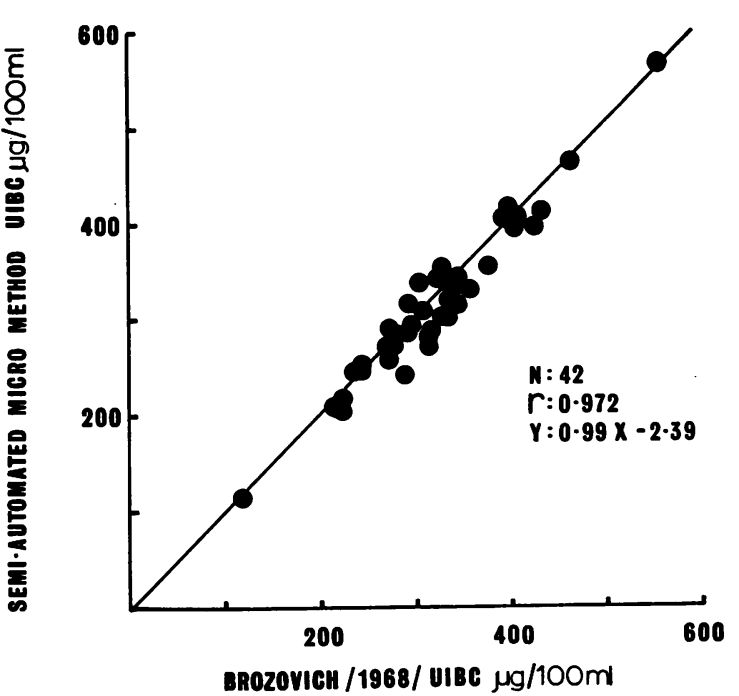

FIG. 1 The correlation of UIBC values measured by the semi-automated micromethod and the method of Brozovich (1968). $\mathrm{N}=$ number of duplicate estimations, $\mathrm{r}=$ coefficient of correlation, $\mathrm{y}=$ regression line.

CORRELATION OF UIBC MEASURED IN DIFFERENT SAMPLES BY SEMI-AUTOMATED MICROMETHOD AND OTHER METHODS The correlation between the UIBC of serum samples ranging from 100 to $600 \mu \mathrm{g}$ $\mathrm{Fe} / 100 \mathrm{ml}$ measured by the semi-automated micromethod and the method of Brozovich (1968) is shown in Figure 1. There is a very good correlation between measurements of UIBC by both methods $(r=0.972)$. Furthermore, determination of the UIBC by the method of Caraway (1963) and Garry and Owen (1967) was carried out on a small number of the sera (Table III). There was no appreciable difference between the UIBC measured by all four methods.

\section{DISCUSSION}

Statistical analysis of the results obtained by the semi-automated micromethod for the determination of UIBC in serum and a manual method (Brozovich, 1968) showed that both methods are equally reproducible and that there is very good agreement between values for UIBC measured by these methods (Table I, Fig. 1). A further comparison of the UIBC measured both by the present method and the method of Brozovich (1968) was made on a small number of the sera using the methods of Caraway (1963) and Garry and Owen (1967) (Table III). Good agreement 
TABLE III

COMPARISON OF UIBC OBTAINED BY SEMI-AUTOMATED MICROMETHOD AND BY METHODS OF BROZOVICH (1968), CARAWAY (1963), AND GARRY AND OWEN (1967)

\begin{tabular}{|c|c|c|c|c|}
\hline \multirow[b]{2}{*}{$\begin{array}{l}\text { Sample } \\
\text { No. }\end{array}$} & \multicolumn{2}{|c|}{$\begin{array}{l}\text { Methods Using Radioactive } \\
\text { Iron }(\mu \mathrm{g} / 100 \mathrm{ml})\end{array}$} & \multicolumn{2}{|c|}{$\begin{array}{l}\text { Colorimetric Methods } \\
(\mu \mathrm{g} / 100 \mathrm{ml})\end{array}$} \\
\hline & $\begin{array}{l}\text { Semi- } \\
\text { automated } \\
\text { Micro- } \\
\text { method }\end{array}$ & $\begin{array}{l}\text { Brozovich } \\
(1968)\end{array}$ & $\begin{array}{l}\text { Caraway } \\
(1963)\end{array}$ & $\begin{array}{l}\text { Garry and } \\
\text { Owen (1967) }\end{array}$ \\
\hline $\begin{array}{l}1 \\
2 \\
3 \\
4 \\
5 \\
6 \\
7 \\
8 \\
9 \\
10 \\
11 \\
12\end{array}$ & $\begin{array}{l}240 \\
274 \\
194 \\
324 \\
218 \\
179 \\
203 \\
239 \\
237 \\
332 \\
273 \\
195\end{array}$ & $\begin{array}{l}217 \\
261 \\
223 \\
322 \\
231 \\
175 \\
208 \\
248 \\
235 \\
362 \\
239 \\
217\end{array}$ & $\begin{array}{l}209 \\
232 \\
199 \\
324 \\
217 \\
162 \\
217 \\
238 \\
269 \\
340 \\
240 \\
201\end{array}$ & $\begin{array}{l}224 \\
265 \\
202 \\
325 \\
239 \\
205 \\
223 \\
259 \\
257 \\
365 \\
250 \\
210\end{array}$ \\
\hline
\end{tabular}

${ }^{1}$ Unsaturated iron-binding capacity was calculated by subtraction of serum iron from total iron-binding capacity.

between UIBC measured by all four methods was found.

Using the method described for UIBC determination the rate of analysis was increased up to 200 sera per day. This was due mainly to the introduction of autodiluters which made pipetting unnecessary. As disposable plastic tubes are used throughout the test there is no additional load on general washing-up procedures. However, such a large number of tubes demands a large-capacity centrifuge and an automatic radioactivity counter.

It is possible that the volume of serum necessary for the determination of UIBC could be reduced even further without affecting the reproducibility. This was also reported by Lee and Chiamori (1961). $\vec{F}$ However, in the present technique the procedure for determining UIBC on $0.1 \mathrm{ml}$ of serum does not require the special care and equipment necessary for a microtechnique.

It is a pleasure to thank Professor D. L. Mollin for his encouragement and valuable advice. This work was $\vec{O}$ financed in part by a grant from the World Health $\overrightarrow{-}$ Organization.

\section{REFERENCES}

Barber, A. A., Dempster, C., and Anderson, N. G. (1963). Clin. chim. Acta, 8, 143 .

Bothwell, T. H., and Finch, C. A. (1962). Iron Metabolism. Churchill, o London.

—, Jacobs, P., and Kamener, R. (1959). S. Afr. J. med. Sci., 24, 93.

Brozovich, B. (1968). J. clin. Path., 21, 183.

Caraway, W. T. (1963). Clin. Chem., 9, 188.

Clarke, D. D., and Nicklas, R. (1967). In Automation in Analyticato Chemistry (Technicon International Symposium, 1966), edited by L. T. Skeggs, p. 19, New York

Garry, P. J., and Owen, G. M. (1967). Ibid, p. 18.

Giovanniello, T. J., Di Benedetto, G., Palmer, D. W., and Peters, T., Jr. (1968). J. Lab. clin. Med., 71, 874.

Herbert, V., Gottlieb, C. W., Lau K. S., Fisher, M., Gervitz, N. R., $\overrightarrow{0}$ and Wasserman, L. R. (1966). Ibid, 67, 855.

Jager, B. V., and Gubler, C. J. (1952). J. Immunol., 69, 311.

Laurell, C. B. (1947). Acta, physiol, scand, 14, suppl. 46.

Lee, N. D., and Chiamori, N. (1961). Clin. chim. Acta, 6, 624.

Ramsey, W. N. M. (1957). Ibid, 2, 221.

Rodgerson, D. O., and Helfer, R. E. (1966). Ibid, 12, 338.

Soothill, J. F. (1962). J. Lab. clin. Med., 59, 859.

Tauxe, W. N. (1961). Amer. J. clin. Path., 35, 403.

Watkins, D. K., and Butler, E. B. (1966). Clin. chim. Acta, 13, 449.

Young, D. S., and Hicks, J. M. (1965). J. clin. Path., 18, 98.

Zak, B., and Epstein, E. (1964). In Automation in Analytical Chemistry (Technicon International Symposium). Paper 56. New York.

Zettner, A., Sylvia, L. C., and Capacho-Delgado, L. (1966). Amer. J. clin. Path., 45, 533. 